\title{
EКОНОМІКА НАФТОГАЗОВОГО КОМПЛЕКСУ
}

УДК 338.45:622.32

JEL O 13, L71, Q 32

DOI: 10.31471/2409-0948-2019-1(19)-40-52

\author{
Пілка Микола Степанович \\ здобувач \\ Івано-Франківський національний технічний університет нафти і газу \\ 76019, Івано-Франківськ, вул. Карпатська, 15 \\ e-mail: 89muk@ukr.net \\ ORCID https://orcid.org/0000-0003-2307-7644

\section{ЕКОНОМІЧНИЙ СУПРОВІД ІННОВАЦЙНИХ ТЕХНОЛОГІЙ РОЗРОБКИ РОДОВИЩ ВУГЛЕВОДНІВ 3 ВАЖКОВИДОБУВНИМИ ЗАПАСАМИ}

Анотація. У статті розглянуто можливості залучення інвестицій для ефективного вилучення запасів вуглеводнів, які відносяться до категорії важковидобувних та механізми залучення інвестицій в дорозробку нафтогазових родовищ в Україні.

Розглянуто основні принципи ранжування запасів вуглеводнів, аналіз структури запасів, необхідний для оцінення перспектив переводу їх частини в рентабельні у разі зміни економічних умов, а також за появи нових методів і технологій залучення запасів у розробку. Крім того, для нафтогазових компаній є дуже важливою інформація про якісну характеристику рентабельних запасів і їх розподіл по продуктивних пластах родовища.

Описано основні переваги використання технологій інтелектуальних нафтогазових родовищ, які дають можливість в режимі реального часу швидко обробити великі обсяги геологічної інформації, змоделювати різні сценарії розробки, прийняти виважені управлінські рішення для оптимізації нафтогазовидобування.

Охарактеризовано основні принципи гідродинамічного моделювання, як важливого інструменту пошуку та приросту запасів вуглеводнів, а також детального комплексного вивчення продуктивних колекторів на основі сучасних досягнень геологічних та геофізичних наук, що є одним з основних шляхів освоєння важковидобувних запасів вуглеводнів. Застосування сучасних і створення нових технологічних рішень для ефективного видобування нафти і газу за позитивних економічних показників є логічним продовженням комплексу робіт на низькорентабельних родовищах вуглеводнів. Основним джерелом приросту запасів вуглеводнів на родовищах 3 тривалою історією розробки є невиявлені поклади за межами продуктивної частини розрізу родовища та пропущені нафтонасичені інтервали в його межах; нафтонасичені інтервали в продуктивній частині розрізу, які слабо або зовсім не задіяні в розробці.

Розробка родовищ 3 важковидобувними запасами пов'язана зі значними труднощами, проте інженерний підхід 3 використанням моніторингу розробки, гідродинамічне моделювання, залучення міжнародного досвіду i нових технологій дозволить підвищити рентабельність і отримати додатковий видобуток значних обсягів вуглеводнів, що забезпечить не тільки досягнення максимальної ефективності інвестицій, але й найповніше використання природних ресурсів вуглеводнів.

Ключові слова: вуглеводні, важковидобувні запаси, структура запасів, рентабельні запаси вуглеводнів, продуктивність свердловин, технологія інтелектуальних нафтогазових родовищ, ефективність інвестицій. 


\title{
Pilka Mykola Stepanovych
}

getter

\author{
Ivano-Frankivsk National Technical University of Oil and Gas \\ 76019, Ivano-Frankivsk, st. Carpathian, 15 \\ e-mail: 89muk@ukr.net
}

\section{ECONOMIC SUPPLY OF INNOVATIVE TECHNOLOGIES FOR THE DEVELOPMENT OF HYDROCARBON DEPOSITS WITH HARDRECOVERABLE RESERVES}

\begin{abstract}
The possibilities of attraction of investments for efficient removal of hydrocarbon reserves, which belong to hardrecoverable and mechanisms for attracting investments in the further development of oil and gas deposits in Ukraine, are presented.

The main principles of the ranking of hydrocarbon reserves are considered, deposits structure analysis is needed to evaluate the prospects of transferring their parts to cost-effective ones if some economic conditions will change, as well as the appearance of new methods and technologies for attracting these reserves into development. For oil and gas companies information about the qualitative characteristics of profitable reserves and their distribution in the collectors is very important.

The main advantages of using intelligent oil and gas field technologies, which enable realtime realization of fast processing of large volumes of geological information, modeling of various extraction scenarios, and the adoption of rational management decisions for optimizing oil and gas production are described.

Hydrodynamic modeling, as an instrument for the search and growth of hydrocarbon reserves, its quantitative and qualitative assessment and a detailed comprehensive study of productive collectors based on modern achievements in geological and geophysical sciences is one of the main ways of development of hardrecoverable reserves. The application of existing and the creation of new technological solutions for the efficient production of oil and gas with positive economic indicators, is a logical continuation of a complex of works on low-yielding hydrocarbon deposits. The main source of growth of hydrocarbon reserves in deposits with a long history of development are: unidentified reserves outside the productive part of the deposit and missed oil-saturated intervals; oil-saturated intervals in the productive section, which aren't attracted in the development.

The development of hardrecoverable reserves is associated with considerable complexity, but the engineering approach, using development monitoring, hydrodynamic modeling, attracting international experience and new technologies, will increase profitability and obtain additional extraction of significant volumes of hydrocarbons, which will ensure not only the achievement of maximum investment efficiency, but also full usage of natural resources of hydrocarbons.
\end{abstract}

Key words: hydrocarbons, hardrecoverable reserves, reserves structure, profitable hydrocarbon reserves, wells productivity, technology of intelligent oil and gas fields, investment efficiency.

Вступ. Основними шляхами забезпечення енергетичної незалежності України $\epsilon$ нарощування власного видобутку вуглеводнів шляхом розширення можливих джерел видобування нафти та газу, впровадження нових ефективних видобувних технологій. Постійне зменшення обсягів геологорозвідувальних робіт (ГРР) призвело до того, що за останні 20 років на території України не було відкрито родовищ зі значними запасами нафти чи газу. Це спричинило значну диспропорцію між щорічним приростом запасів нафти і газу за рахунок відкриття нових родовищ та їхнім видобутком.

Відповідно до опублікованого у 2016 р. огляду British Petroleum Energy Outlook [1], світові потреби в енергії до 2035 р. зростуть на 34 \% порівняно з 2014 р., збільшуючись 
щорічно в середньому на $1,4 \%$. Домінуючу роль в паливно-енергетичному балансі відіграватимуть видобувні види енергетичних ресурсів. Незважаючи на швидкий ріст використання інших джерел енергії, прогнозують, що видобувні енергетичні ресурси задовільнятимуть у 2035 р до $60 \%$ від зростання потреб в енергії, а їх частка становитиме майже $80 \%$ від сумарного світового обсягу споживання енергії. Серед видобувних енергетичних ресурсів найбільшими темпами зростатиме потреба у природному газі. Вона щорічно збільшуватиметься в середньому на $1,8 \%$. Збільшуватимуться і потреби в нафті (в середньому на 0,9 \% за рік), але її частка в енергетичному балансі продовжуватиме падати.

Україна володіє достатніми ресурсами як традиційного, так і нетрадиційного газу, що дає змогу сподіватися збільшення його загального видобутку до 2030 р. на 23 - 25 млрд. ${ }^{3} /$ рік порівняно 3 теперішнім рівнем і досягнення загального обсягу видобутку до 45 млрд $\mathrm{m}^{3} /$ рік. Прогнозують, що цього приросту можна досягти завдяки збільшенню видобутку традиційних ресурсів газу на 10 млрд $\mathrm{m}^{3} /$ рік (переважно за рахунок освоєння родовищ Чорноморського шельфу) та нетрадиційних ресурсів - на 15 млрд м²/piк [2].

Сьогодні в Україні велика кількість нафтогазових родовищ - на завершальній стадії розробки і характеризуються високим рівнем обводнення продукції та низькими дебітами. Ці родовища відносяться до категорії родовищ із важковидобувними запасами, проте вони $\epsilon$ значним резервом нарощування власного видобутку вуглеводнів та забезпечення на цій основі потреб держави в енергоносіях. До важковидобувних відносяться більше, ніж $72 \%$ запасів нафти, 10 - 15\% запасів природного газу. Окрім цього, 45\% газових родовищ мають початкові видобувні запаси менше за 1 млрд м ${ }^{3}, 88 \%$ нафтових родовищ мають запаси менше від 1 млн т. і за класифікацією відносяться до "дуже дрібних" [3].

Аналіз сучасних зарубіжних і вітчизняних досліджень і публікацій. Проблеми розробки економічних механізмів залучення інвестицій при видобуванні вуглеводнів, підвищення ефективності роботи видобувних свердловин, визначення пріоритетних аспектів стратегічного управління розробкою вуглеводневих родовищ були об'єктами досліджень у численних публікацій широкого кола вчених: Витвицької У.Я. [4], Чорної І. М. [5], Гораль Л. Т., Фадєєвої І. Г. та ін. [6], Витвицького Я. С. [7], Смагіна Т. Н. [8], Карпенка І. О. [9], Кочкодана В. Б. [10], Ходановіча Д., Малкош Р. [11].

Висвітлення невирішених раніше частин загальної проблеми. Низький ступінь використання розвіданих запасів нафти i газу в Україні зумовлює необхідність інвестування науково-технічних розробок і заходів з підвищення нафтогазовидобутку із родовищ, які вже перебувають в експлуатації. Такі заходи потребують значних інвестицій для налагодження процесів буріння нових свердловин та бокових стовбурів у вже існуючих свердловинах, переоблаштування систем збору та обліку вуглеводнів на старих родовищах, придбання новітніх технологій та хімреагентів для інтенсифікації видобутку. Інвестиційні ресурси вітчизняних видобувних підприємств є обмеженими і вимагають детального та об'єктивного обгрунтування при їх використанні. Тому важливою проблемою для подальшого нарощування видобутку вуглеводнів в Україні є не лише пошук та акумуляція інвестиційних ресурсів, але й їх ефективне використання. Проблема підвищення ефективності інвестицій у нафтогазовидобувній галузі України $\epsilon$ актуальною ще й у зв'язку з багатьма ускладнюючими факторами: природними, технологічними, економічними.

Формулювання цілей статті. Метою статті $\epsilon$ обгрунтування шляхів та умов залучення інвестицій для ефективного вилучення запасів вуглеводнів, які за сучасних економічних умов відносяться до категорії важковидобувних за наявних методів і технологій введення запасів цих родовищ у розробку.

Висвітлення основного матеріалу. Розвиток вітчизняного нафтогазовидобування як один зі стратегічних напрямів посилення енергетичної незалежності України можливий за умови поповнення мінерально-сировинної бази новими розвіданими запасами та більш повного вилучення вуглеводнів 3 покладів, промислова розробка яких вже здійснюється. 
Вирішення цих завдань потребує активізації інвестиційної діяльності шляхом залучення інвесторів, які практикують новітні методи та сучасні технології розробки вуглеводнів.

Сьогодні в Україні гостро постає проблема підвищення ефективності роботи видобувних свердловин, економічного обгрунтування методів інтенсифікації видобутку, визначення граничних меж та доцільності подальшої експлуатації свердловин на основі їх мінімально рентабельних дебітів. У ринкових умовах вирішення цих проблем $є$ вкрай важливим завданням. Дослідження методів штучного впливу на об'єкти розробки дає змогу раціонально розробляти поклади вуглеводнів і досягти максимальних коефіцієнтів нафтогазовилучення та збільшення поточних обсягів видобутку. Ці завдання значно ускладнюються при розробці складно побудованих, високо неоднорідних багатопластових покладів та родовищ, запаси яких відносяться до категорії важковидобувних.

Стратегія активізації розробки родовищ 3 важковидобувними запасами вимагає вирішення таких ключових проблем: виявлення родовищ, які можуть бути потенційно прибутковими; в якій формі і де знаходяться залишкові запаси вуглеводнів на цих родовищах; наскільки економічно ефективною буде експлуатація цих родовищ.

У нафтовому бізнесі нафтовіддача не $\epsilon$ першочерговим пріоритетом надрокористувача. Головним тут, як і для будь-якого бізнесу, є задоволення економічних інтересів акціонерів компанії та інвесторів. Як правило, це суперечить досягненню максимально можливих значень нафтовіддачі. Водночас, збільшення нафтовіддачі i найбільш ефективне використання запасів - основна мета власника надр, тобто держави. Тому утримання рівнів видобутку нафти і газу на родовищах 3 важковидобувними запасами вкрай складне і важливе завдання. Для його вирішення перш за все необхідно виділити зони концентрації рухомих залишкових запасів, що зазвичай приурочені до високонеоднорідних колекторів. Достовірне виявлення таких зон і введення їх в активну розробку дозволить обгрунтувати рентабельність подальшої експлуатації родовищ та уникнути витрат, пов'язаних 3 геолого-технічними заходами в низькопродуктивних ділянках. Надзвичайно важливим $є$ визначення ступеня виснаження окремих блоків родовищ та величини потенційно-видобувних запасів. Також на нових ліцензійних ділянках, необхідно оперативно оцінювати рентабельність їх розробки, що потребує нових наукових підходів до вирішення завдань, пов'язаних 3 максимально ефективною експлуатацією родовищ з важковидобувними запасами.

У сучасному світі одним із найпоширеніших та найякісніших інструментів при прийнятті оперативних рішень у процесі розробки нафтогазових родовищ $є$ тривимірне гідродинамічне моделювання. Проте достовірність таких моделей безпосередньо залежить від точності вхідних даних, отриманих в результаті не тільки промислових досліджень, але й підходів до інтерпретації отриманої інформації. Побудова гідродинамічної моделі триває багато часу і вимагає високої кваліфікації інженерно-технічного персоналу, особливо при моделюванні великих об'єктів зі складною будовою та тривалою історією розробки. Для обгрунтування достовірності результатів гідродинамічного моделювання необхідно застосовувати комплексні аналітичні методи, які повинні передувати побудові повномасштабної геологічної моделі. Такі методи дають змогу визначити початкові видобувні запаси вуглеводнів, причини їх фактичного відхилення від раніше затверджених обсягів, виявляти можливості їх значного нарощення [11].

Отже, детальне комплексне вивчення продуктивних колекторів на основі сучасних досягнень геологічних та геофізичних наук, побудова геолого-гідродинамічних моделей, їх адаптація до історії розробки, виявлення залишкових запасів, їх кількісне і якісне оцінення $є$ одним 3 основних шляхів освоєння важковидобувних запасів вуглеводнів. Застосування сьогоднішніх і створення нових технологічних рішень для ефективного видобутку нафти і газу за позитивних економічних показників, є логічним продовженням комплексу робіт на низькорентабельних родовищах вуглеводнів. Основним джерелом приросту запасів вуглеводнів на родовищах з тривалою історією розробки є невиявлені поклади за межами продуктивної частини розрізу родовища та пропущені нафтонасичені 
інтервали в його межах; нафтонасичені інтервали в продуктивній частині розрізу, які слабо або зовсім не задіяні в розробці; цілики нафти та зони підвищеної нафтонасиченості, які сформувалися в процесі розробки родовища [12].

Важливим завданням у сфері надрокористування $\epsilon$ оцінення й облік запасів вуглеводнів та віднесення їх до певних класифікаційних груп. Сьогодні існує ряд класифікацій в оціненні запасів і ресурсів вуглеводнів, серед яких є державні класифікації найбільших нафтовидобувних країн (Китай, Норвегія, Канада), міжнародних організацій $(\mathrm{OOH}, \mathrm{WPC})$, інженерних організацій (SPE, AAPG), бірж цінних паперів та ін. Основною метою державних класифікацій є облік об'ємів нафти і газу, контроль їх видобутку 3 метою розрахунку рентних платежів, вартості ліцензій та спецдозволів. Недержавні класифікації використовують біржі та банки з метою залучення інвестицій, компанії для визначення величини запасів, вилучення яких буде економічно доцільним з врахуванням сучасних технологій за сучасних економічних умов, а також для обліку видобутку та стратегічного планування.

Великі нафтогазові компанії цікавлять не тільки рентабельні, але і нерентабельні, технологічно чи економічно видобувні запаси. Аналіз структури таких запасів необхідний, щоб оцінити перспективи переводення їх частини в рентабельні у разі зміни економічних умов, а також за появи нових методів і технологій залучення даних запасів в розробку. Крім того, для нафтогазових компаній $є$ дуже важливою інформація про якісну характеристику рентабельних запасів і їх розподіл по продуктивних пластах родовища. Така інформація дає змогу будувати профілі видобутку вуглеводнів, 3 певною почерговістю залучення запасів різної якості, у різних економічних сценаріях, що має за мету ефективне управління розробкою низькорентабельних родовищ.

Завдання внутрішнього оцінення запасів, яке стоїть перед видобувною компанією можна вирішити шляхом їх ранжування, на основі набору існуючих категорій запасів, їх геологічної вивченості та економічної ефективності. Тому запаси вуглеводнів умовно розподіляють на категорії: рентабельні, умовно-рентабельні, потенційні і такі, що не мають промислового значення. Це визначають на основі геологічних, технологічних i економічних критеріїв, з метою їх ранжування під буріння, геолого-технічні заходи та виділення перспективних зон для проведення дослідно-промислових робіт. У такому розподілі запасів вуглеводнів основними $\epsilon$ економічні показники, тому що саме економічне оцінення дозволяє визначити корисний результат від інвестицій на конкретній ділянці родовища. Звісно, між економічними показниками і геолого-промисловими характеристиками об'єкта оцінки існує тісний зв'язок. Ділянки з кращими фільтраційноємнісними характеристиками є більш продуктивними і мають кращі економічні показники експлуатації. Інший важливий фактор при оцінці запасів - це стан геолого-геофізичної вивченості. Економічну оцінку можна виконати за різних ступенів вивченості, але похибка таких розрахунків залежить від наявної інформації про досліджуваний об'єкт. Якісні вхідні дані - це комплекс критеріїв, основними 3 яких є розбуреність, дані сейсморозвідки, наявність результатів випробувань, достовірність побудови петрофізичних та PVT моделей та ін.

Отже, для кожної категорії запасів актуальними є різні заходи. Рентабельні запаси є в розбурених зонах, видобуток в яких економічно рентабельний. У таких зонах можлива інтенсифікація видобутку з допомогою залучення запасів різної якості та ущільнюючого буріння.

До умовно-рентабельних відносяться запаси розбурених зон з низькорентабельним видобутком вуглеводнів. Тут рекомендується оптимізація системи підтримки пластового тиску (ППТ), забурка бокових стовбурів, багатостадійний гідророзрив пласта (ГРП) та інші заходи з низько-затратними технологіями.

Потенційні запаси є в зонах складної геологічної будови, де оцінити видобувні запаси складно. В свердловинах цих зон необхідний розширений комплекс гідродинамічних досліджень, відбір керна та флюїдів. Для розробки запасів таких зон, 
необхідно передбачувати дослідно-промислові роботи 3 метою пошуку методів збільшення нафтовіддачі та нових низько-затратних технологій, додаткового буріння розвідувальних свердловин та ін. Також до цієї категорії запасів належать зони проведення повномасштабних пошуково-розвідувальних робіт.

У категорії непромислових запасів виділяють такі зони: розбурені, видобування вуглеводнів у яких економічно не рентабельне в сучасних економічних та технологічних умовах; недовивчені з низькорентабельними запасами, які підтверджені експлуатаційним бурінням або ЗД сейсморозвідкою, розвідувальним бурінням; найменш вивчені зони 3 нерентабельними запасами. Щоб перевести у вищі категорії, запаси цих зон потребують певних заходів, які дозволять значно скоротити витрати, пов'язані з їх розробкою. Зі сторони держави це можуть бути податкові пільги. Тому технологія ранжування запасів дозволяє керувати ними та розглядати різні варіанти розробки об'єкта 3 врахуванням геологічних ризиків і можливої економічної ефективності [8].

Отже, управління запасами вуглеводнів можливе шляхом їх умовного розподілу, що дозволяє виділити ділянки для буріння нових свердловин, планувати геолого-технічні заходи, дослідно-промислову розробку, геологорозвідувальні роботи. Також стає можливим оцінити важковидобувні запаси і їх величини, з якими нафтогазовидобувна компанія зможе працювати за певних податкових пільг, появи нових прогресивних технологій або інших економічних факторів, які дозволять значно скоротити експлуатаційні витрати.

Як вже зазначено вище, у структурі запасів вуглеводнів постійно збільшується частка важковидобувних запасів, освоєння яких в сучасних економічних умовах пов'язане зі значними інвестиціями. Тому розробка родовищ із важковидобувними запасами нафти здійснюється низькими темпами i, як показує досвід, кінцева нафтовіддача продуктивних пластів цих родовищ не перевищує 30 \% від початкових балансових їх запасів [13]. Обсяг таких запасів за останній 30-річний період в Україні збільшився майже втричі та перевищив 70 \% від загальних запасів. В Україні це насамперед запаси нафти у малопроникних колекторах, залишкові запаси вуглеводнів, які формуються на пізній стадії розробки родовища, високо обводнені поклади, важка високов’язка нафта і бітуми. Усе це важливі напрями освоєння вуглеводневого потенціалу надр у сучасних умовах, яке сьогодні успішно реалізують у США і Канаді. Для України освоєння таких запасів також $є$ вкрай актуальним, хоча сьогодні їм не приділяють належної уваги.

Критерії, за якими категорію запасів визначають як важковидобувні, окреслені у постанові КМ України від 7 листопада 2013 року №838 [14]. Такими визнано ділянки, вилучення запасів вуглеводневої сировини з яких ускладнене хоча б одним із критеріїв: залягання нафти в пластових умовах є високов'язким (з динамічною в'язкістю в пластових умовах понад 30 мПа·с); колектори ділянок надр, у яких розміщені запаси вуглеводневої сировини, є низькопроникними (менше, ніж 0,05 мкм² для нафти, і менше за 0,02 мкм² для природного газу); запаси нафти локалізовані у нафтових облямівках і підгазових зонах нафтогазоконденсатних родовищ 3 висотою нафтового покладу - меншою, як 30 метрів, $\mathrm{i}$ шириною - не більше, як 200 метрів; ступінь вироблення початкових видобувних запасів нафти становить понад $80 \%$, природного газу - понад $85 \%$; середня обводненість продукції нафтових покладів становить понад $80 \%$ за умови вилучення понад $60 \%$ початкових видобувних запасів; у покладах газу з активним водонапірним режимом вилучено понад 40 \% початкових балансових запасів газу; у газоконденсатних покладах 3 початковим вмістом конденсату в пластовому газі понад 200 г/куб. метр вилучено понад $40 \%$ початкових балансових запасів газу; газоконденсатні поклади 3 початковими балансовими запасами газу становлять менше за 0,5 млрд м $^{3}$; родовища розташовані у морських акваторіях.

Можливе виділення важковидобувних запасів за критичним, 3 точки зору можливості видобування вуглеводнів, значенням одного із геолого-фізичних параметрів. Проте необхідно враховувати, що до аналогічного результату про неможливість видобути 
вуглеводні може привести і використання сукупності декількох геологічних факторів, кожен 3 яких не є критичним. Тому підхід, який базується на використанні сукупності основних геолого-фізичних параметрів покладів вуглеводнів, які характеризують фільтраційні процеси флюїдів в пластах, є більш коректним для обгрунтування віднесення запасів до категорії важковидобувних. Як комплексний параметр можна використати такий показник, як гідропровідність пласта. Цей параметр визначає найважливіші колекторські властивості та параметри роботи будь-якого покладу, а саме: проникність, ефективну потужність, а також в' язкість нафти, і характеризує продуктивність пласта. Від величини коефіцієнта гідропровідності суттєво залежить дебітність свердловин конкретного родовища (покладу, пласта). Тому цей показник є одним з основних природогеологічних факторів для нафтових покладів. Чим вищий коефіцієнт гідропровідності, тим сприятливіші умови розробки родовища, а отже, податкове навантаження також повинно бути більшим і, відповідно, навпаки.

Більш досконалим методом виділення важковидобувних запасів є використання багатопараметричних залежностей певного критерію складності від геолого-фізичних параметрів покладів. Можливості використання алгоритму нечіткої кластеризації Fuzzy cmeans в обгрунтуванні віднесення запасів до категорії важковидобувних на родовищі Daqing (PetroChina, Китай) описано в роботі [15]. Основними факторами, які визначали ступінь складності вилучення запасів нафти, $\epsilon$ ефективна товщина, пористість, проникність, початкова нафтонасиченість пласта, розміри і геологічні запаси покладу, щільність запасів нафти, середня глибина пласта, а також властивості нафти (об'ємний коефіцієнт, газовміст, густина в поверхневих умовах). Також автори цієї роботи класифікували різні ділянки покладу залежно від ступеня можливості залучення їх до розробки.

У роботі [16] використано підхід для визначення складності родовища з точки зору досягнення величини кінцевого вилучення нафти (КВН). Він базується на використанні індексу складності пласта RCI (Reservoir Complexity Index), який формується шляхом аналізування геолого-фізичних характеристик пласта. У процесі досліджень було виявлено хорошу кореляційну залежність між RCI та величиною КВН. Геолого-фізичними параметрами, які характеризують якість покладу та формують величину RCI $\epsilon$ проникність пласта, контраст проникності пласта (десятковий логарифм співвідношення проникності найбільш та найменш проникних елементів пласта - шарів чи фацій), вертикальна і горизонтальна зв'язаність пластів, щільність запасів нафти. Для кожного 3 виділених параметрів визначено індекс складності від 1 до 5. Для покладу, що аналізується за кожним параметром, присвоюють значення індексу складності, яке базується на об'єктивних границях і суб' єктивних оцінках. Значення індексів параметрів нормалізують від 1 до 0. Індекс RCI формується на основі нелінійних комбінацій індексів окремих параметрів. Високі значення індексу означають більш складний резервуар.

Звісно, що в дослідженні важковидобувних запасів потрібно використовувати не тільки технологічні, але й економічні показники, тобто важковидобувними необхідно вважати ті запаси, які не можливо ефективно вилучити в економічних умовах з сучасними технологіями. Тому обгрунтування віднесення запасів родовища до даної категорії має базуватися на основі повного техніко-економічного розрахунку показників розробки родовища. В роботі [17] описано методологію віднесення запасів до категорії важковидобувних, яка базується на показнику питомого накопиченого вилучення нафти на одну експлуатаційну свердловину, який забезпечував окупність капітальних i експлуатаційних витрат. Як параметри фільтраційно-ємнісних властивостей пластів і характеристик флюїдів використовували проникність пласта, в'язкість нафти, щільність запасів нафти, приведений коефіцієнт піщаності i Dykstra-Parson (ці коефіцієнти характеризують ступінь залучення пластів витісненням). Для параметрів фільтраційноємнісних властивостей пластів у заданому діапазоні їх зміни розраховували накопичений видобуток нафти за заданий період розробки покладу. Рівняння регресії питомого 
накопиченого видобутку нафти використовували для побудови таблиці 3 коефіцієнтами складності параметрів фільтраційно-ємнісних властивостей. Таку таблицю застосовують для виділення важковидобувних запасів вуглеводнів на основі розрахунку індексу складності запасів. Отже, використання в якості критеріїв окремих параметрів пластів без врахування інших може призвести до виключення з категорії важковидобувних значної кількості запасів вуглеводнів, розробка яких в сучасних умовах $\epsilon$ нерентабельною, а тому вони можуть бути залучені до розробки тільки за відповідної стимуляції.

Не менш важливим аспектом зростання власного видобутку вуглеводнів в Україні $\epsilon$ використання технологій інтелектуальних родовищ. Інтелектуальне нафтогазове родовище - це система контролю й управління нафтогазовими операціями в режимі реального часу, яка забезпечує безперервну оптимізацію інтегрованої моделі пласта i моделі управління видобутком для підвищення видобутку вуглеводнів i скорочує операційні та капітальні витрати [18].

Метою використання моделі інтелектуального нафтогазового родовища $\epsilon$ максимізація видобутку вуглеводнів, зменшення непродуктивного часу роботи, а також підвищення прибутковості шляхом розробки і впровадження інтегрованих робочих процесів. Робочі процеси моделей інтелектуальних нафтогазових родовищ поєднують управління бізнесовими процесами разом із новітніми інформаційними технологіями та інженерними знаннями. Основними цілями інтелектуального родовища $\epsilon$ інтеграція нафтогазових технологій, інформаційних потоків, зниження експлуатаційних витрат на 5 $\%$, капітальних витрат - на $10 \%$, підвищення продуктивності технологічних операцій, досягнення кінцевого коефіцієнта вилучення нафти - 50 \%, і коефіцієнта видобутку газу $90 \%$.

Цифрові технології управління нафтовіддачею дають можливість вирішити в режимі реального часу такі цілі та завдання: швидка обробка великих обсягів геоінформації, моделювання різних сценаріїв видобутку, максимізація і досягнення високих темпів видобування вуглеводнів, прийняття виважених управлінських рішень для оптимізації нафтогазового виробництва. Інтелектуальне родовище не може існувати за відсутності важливої інформації з видобувних свердловин про стан ресурсів [10].

Моделі інтелектуальних нафтогазових родовищ покликані компенсувати більш високу складність і вартість операцій, які виконує менша кількість низькокваліфікованих співробітників. Можна сказати, що моделі інтелектуальних нафтогазових родовищ - це набори робочих процесів, які дозволяють швидке, спільне виконання взаємопов'язаних завдань серед розподілених команд, 3 кінцевим результатом, який $є$ оптимальним, ефективним і більш прибутковим [19].

На даному етапі розвитку використання технологій інтелектуальних родовищ має такі переваги для підприємств видобувної галузі України: оптимізація продуктивності обладнання і продуктивності свердловин завдяки аналізу дебетів, тисків, температур та інших даних; передбачення, на основі минулих даних термінів виснаження свердловин. Одночасно використовувати результати експлуатації старих свердловин 3 багатою історією видобутку можна застосовувати для прогнозування роботи нових свердловин, централізованого управління великою кількістю свердловин за допомогою систем дистанційного моніторингу [20].

Застосування всіх цих новітніх технологій розробки родовищ з важковидобувними запасами вимагає використання i новітніх методичних підходів до обгрунтування інвестиційних рішень, які б відповідали економічним реаліям, враховували світові тенденції розвитку нафтогазовидобування та високий ступінь ризиків і невизначеності у реалізації проектів у цій галузі.

Відомо, що основним інструментом оцінення ефективності інвестиційних проектів, зокрема й у нафтогазовидобувній галузі, є метод дисконтування грошових потоків, який базується на концепції врахування зміни вартості грошей у часі під впливом численних факторів. Найважливішим 3 них $\epsilon$ здатність грошей приносити дохід за умови їх 
інвестування в альтернативні проекти із мінімальними ризиками або нормами доходу, які 6 компенсували підвищений рівень ризику. Проте методика дисконтування суттєво знецінює вартість майбутніх грошових потоків, що особливо гостро проявляється, коли період прогнозування перевищує 5 - 10 років. Тому запропоновано новий підхід до врахування фактора часу в оцінюванні ефективності інвестиційних проектів. Суть підходу полягає в тому, що життєвий цикл будь-якого інвестиційного проекту доцільно поділити на три періоди (фази): період здійснення інвестиційних витрат (будівництва), період окупності (реабілітації) та постокупний (основний експлуатаційний) період. Для кожного періоду необхідно застосовувати відповідні процедури врахування фактора часу та різні ставки дисконту і норми доходів, що враховують відповідні ризики, як на ринку реального інвестування, так і на альтернативному ринку цінних паперів [21].

Зрештою, важливе значення має інвестиційна привабливість видобувної індустрії. Аналіз дає висновки щодо неконкурентоспроможності України поміж країн східної Європи та Північної Америки та відсутності навіть гіпотетичної рентабельності видобування нетрадиційних типів вуглеводнів в Україні. За умови ідентичної продуктивності свердловин в Україні, країнах Східної Свропи та Північної Америки, інвестор отримає різний прибуток на вкладені кошти. Рентабельність видобування газоконденсату з різних глибин в Україні на $20 \%$ менша, ніж у Техасі, на $44 \%$ менша, ніж в канадській провінції Альберта, та на 42 - 46 \% менша, ніж у Польщі та Румунії. А період окупності свердловин в Україні вдвічі довший, аніж в Польщі та Румунії. Рентабельність видобутку української нафти на $42-48$ \% нижча, ніж у Східній Європі та Канаді та на 20 $\%$ нижча, аніж у Техасі. Видобування нетрадиційних типів нафти та газу за допомогою буріння горизонтальних свердловин 3 багатостадійними гідророзривами (ГРП) $\epsilon$ нерентабельним в Україні, навіть за умови наявності геологічних формацій аналогічних Північній Америці. Податкова реформа в Альберті створила найпривабливіші умови для інвестицій, рентабельність видобування сланцевої нафти та газу в Альберті на 45 \% більша аніж в Техасі та на 52 \% рентабельніша, аніж в Польщі та Румунії, через нерозвинений сервісний інжиніринговий ринок. Період окупності горизонтальних свердловин в Альберті вдвічі коротший, аніж в Польщі чи Румунії. Щодо рентабельності компаній з пошуків та видобутку сланцевих вуглеводнів в країнах Східної Європи, то умови в Румунії та Польщі є близькі до однакових. Проте видобуток газу щільних колекторів вертикальними свердловинами в країнах Східної Свропи є привабливішим, аніж в Північній Америці, через вищі ринкові ціни на природній газ, в середньому рентабельність більша на $35 \%$.

3 метою адаптації умов функціонування українського видобувного ринку до низьких цін на видобувні енергоносії, повернення інвестиційної привабливості та урівноваження інтересів бізнесу та держави вкрай необхідні реформи сьогоднішніх правил оподаткування нафтогазвидобутку. Найоптимальніший та найгнучкіший механізм оподаткування сьогодні діє в канадській провінції Альберта, він враховує всі аспекти видобування 3 нових та виснажених родовищ чи сланцевих товщ в широкому діапазоні глибин, обмежує вірогідність неприбутковості інвестицій та враховує зміни ринкових цін. Для повернення українському видобувному ринку привабливості, зниження ставок податків має зменшити податкове навантаження до середньозваженого рівня в країнах Східної Європи та нижчого, ніж середньозважений в Північній Америці [9].

Тому, надзвичайно важливим фактором збільшення видобутку вуглеводнів в Україні $\epsilon$ регулююча роль держави, тобто гнучка державна політика у законодавчій, виконавчій та податковій сферах, що дозволить зберегти баланс інтересів держави та надрокористувача. Оскільки нераціональна робота Державної служби надр та геології, бюрократичні бар'єри для отримання ліцензій та спецдозволів може заблокувати діяльність видобувних компаній. Регуляторна функція держави може призвести до примусової зупинки видобувних свердловин, внаслідок чого втрати вуглеводнів будуть безповоротними, а 
враховуючи втрати державного бюджету у зв'язку з недоотриманням рентних платежів наслідком такої діяльності буде крок назад на шляху до енергонезалежності України.

У роботі [22] ми пропонуємо підхід, який дає змогу диференціювати рентні платежі залежно від факторів, що мають найбільший вплив на формування собівартості видобування нафти, а саме: глибини залягання продуктивних покладів та коефіцієнтів гідропровідності.

Застосування цього підходу до диференціації рентних платежів не зменшить величину надходжень до бюджету, бо видобувні підприємства, що розробляють найкращі родовища і поклади, сплачуватимуть більші податки. 3 іншого боку, ті підприємства, які розробляють родовища з важковидобувними запасами, отримуватимуть значну економію коштів, які вони зможуть використати на модернізацію своїх виробничих потужностей, впровадження сучасних методів підвищення нафтовіддачі та геолого-технічні заходи на свердловинах з метою нарощування обсягів видобування вуглеводнів.

Висновки. Розробка родовищ з важковидобувними запасами пов'язана зі значними труднощами, проте інженерний підхід 3 використанням моніторингу розробки, гідродинамічного моделювання, залучення міжнародного досвіду i нових технологій дозволить підвищити рентабельність і отримати додатковий видобуток значних обсягів вуглеводнів, що забезпечить не тільки досягнення максимальної ефективності інвестицій, але й найповніше використання природних ресурсів вуглеводнів.

Облік запасів вуглеводнів та віднесення їх до певних класифікаційних груп $\epsilon$ важливим завданням в управлінні запасами вуглеводнів. Розподіл запасів за певними критеріями дає змогу виділити перспективні неохоплені розробкою ділянки родовищ, а також оцінити важковидобувні запаси, з якими видобувна компанія зможе працювати за умови зменшення податкового навантаження, появи нових технологій або будь-яких інших факторів, що значно скоротить експлуатаційні витрати при розробці родовищ 3 важковидобувними запасами.

Процес віднесення запасів вуглеводнів певного родовища до категорії важковидобувних потребує певного вдосконалення. Використання існуючого механізму виділення важковидобувних запасів за критичними значеннями одного з геолого-фізичних параметрів покладів не охоплює всі запаси вуглеводнів, які неможливо ефективно вилучити в сучасних економічних умовах 3 наявними технологіями. Тому підхід, який базується на використанні сукупності основних геолого-фізичних параметрів покладів вуглеводнів $\epsilon$ більш коректним для обгрунтування віднесення запасів до категорії важковидобувних.

Значного зростання видобутку вуглеводнів в Україні не можна досягти за сучасної системи оподаткування та рівня розвитку сервісного ринку. Потенційно довгостроковим кінцевим результатом реформи оподаткування $є$ імпортозаміщення за рахунок власного видобутку, що є досяжним за умови покращення інвестиційного клімату та залучення міжнародного мобільного капіталу, націленого на видобування вуглеводнів. Гнучка державна політика у законодавчій, виконавчій та особливо податковій сферах дасть змогу зберегти баланс інтересів держави та надрокористувача, що є надзвичайно важливим фактором збільшення власного видобутку вуглеводнів.

Подальший розвиток нафтогазової галузі потребує значного залучення інвестицій як у родовища, які розробляються, для оновлення діючих фондів, так і для ділянок, які є на стадії геологорозвідувальних робіт і проектування видобутку.

Незважаючи на важливу роль видобувної галузі для забезпечення сталого розвитку вітчизняної промисловості та гарантування економічної безпеки України, сьогодні відтворення i приріст видобувних запасів вуглеводнів активно наближається до критичного рівня, за яким можуть розпочатися безповоротні процеси руйнування галузі. Створення ефективної, конкурентоздатної, економічно доцільної видобувної галузі дозволить здійснити реальний перехід національної економіки від сировинно-експортного до ресурсно-інноваційного етапу розвитку. 


\section{Література}

1. British Petroleum: Fossil fuels to remain "dominant form of energy" through 2035 / by Oil\&Gas Journal editors // Oil\&Gas Journal. - 2016. - [Електронний ресурс]. - Режим доступу: http://www.ogj.com/articles/2016/02/bp-fossil-fuels-remain-dominant-form-of-energythrough-2035.html (Дата звернення 03.02.2019 p.)

2. Розвиток газового сектору України в контексті Євроінтеграції // Центр Разумкова. - 2014. - [Електронний ресурс]. - Режим доступу: http://www.razumkov.org.ua/upload/1392037862_file.pdf (Дата звернення 03.05.2018 p.)

3. До прогнозу освоєння вуглеводневих ресурсів східної частини ДДЗ / О. Карпенко, В. Михайлов, І. Карпенко // Вісник Київського національного університету імені Тараса Шевченка. - 2015. - №1(68). - С.49-54

4. Витвицька У.Я. Ефективність інвестицій у дорозробку нафтових родовищ України: Автореф. дис. на здобуття наук. ступеня кандидата економічних наук: 08.07.01 / Інститут економіки НАН України. - К., 2003. - 20 с.

5. Чорна I.M. Економічна оцінка нафтових родовищ (на прикладі Передкарпатського нафтогазоносного басейну): Автореф. дис. на здобуття наук. ступеня кандидата економічних наук: 08.07.01 / Інститут економіки НАН України. - К., 1999. $18 \mathrm{c}$.

6. Фінансові аспекти інноваційного розвитку нафтогазового комплексу України [Текст]: монографія / Л. Т. Гораль, І. Г. Фадєєва та ін. - Івано-Франківськ: ІФНТУНГ, 2016. - 325 c.

7. Оцінка ефективності інвестицій у розвідку і розробку нафтових родовищ [Текст]: монографія / Я.С. Витвицький, У.Я. Витвицька, І.М. Метошоп, І.Р. Михайлів. Івано-Франківськ: ІФНТУНГ, 2006. - 248 с.

8. Принципы ранжирования запасов углеводородов / Т.Н. Смагина, С.Ф. Хафизов, И.И Дьяконов, А.Н. Шандрыгин // Нефтяное хозяйство. - 2012. - №1. C. $20-23$

9. Карпенко I. О. Інвестиційна привабливість, конкурентоспроможність та оподаткування нафтогазовидобувної індустрії в країнах північної Америки, східної Європи та України / I. О. Карпенко, О. С. Веднєєв, О. В. Літвінов, І. П. Середа, О. Б. Мельник // Матеріали IV Міжнародної науково-практичної конференції "Надрокористування в Україні. Перспективи інвестування" - К.: ДКЗ, 2017. - Т. 1. - 302 с.

10. Кочкодан В. Б. Переваги використання технологій інтелектуальних нафтогазових родовищ в Україні // Тези доповіді на IV Міжнародній науково-практичній конференції "Теорія i практика стратегічного управління розвитком галузевих i регіональних суспільних систем" - Івано-Франківськ: 2017. - С.142-145

11. Rapid method for oil-field development assessing / D. Khodanovich, R. Malkosh // Oil Industry Journal. - 2017. - [Електронний ресурс]. - Режим доступу: Www.onepetro.org/journal-paper/OIJ-2017-06-084-087-RU (Дата звернення 03.02.2019р.)

12. Re-activation of Multilayer Oil Field Development at the Late Stage of Production / Rasim N. Diyashev, N. Nurislamov, V. Voronovsky // Society of Petroleum Engineers. - 2006. - [Електронний ресурс]. - Режим доступу: www.onepetro.org/conference-paper/SPE-104361MS (Дата звернення 03.02.2019 р.)

13. Гнип М.П. Принципы стабилизации уровня добычи нефти на поздней стадии разработки месторождений / М.П. Гнип, В.Й. Прокопив, В.М. Дорошенко // Problemy techniczne i technologiczne pozykiwania weglowodorow a zrownowazony rozwoj gospodarki. - Prace Instytutu Nafty I Gazu. - 2006. - № 137. - c. 801-808.

14. Деякі питання виконання діючих та нових інвестиційних проектів (програм, договорів), якими передбачено нарощування видобутку вуглеводневої сировини: постанова КМУ від 7 листопада 2013 року №838. Офіційний сайт Кабінету Міністрів України. - Режим доступу: http://zakon5.rada.gov.ua/laws/show/838-2013-п (Дата звернення 03.05.2018 p.). 
15. Zhi, Li Classification of Hard-to-Recover Reserves Based on FCM and Combination weighting approach / Zhi, Li; Juan, Yang; Kejun, Zhu // Wuhan International Conference on e-Business 2013 Proceedings. - 2013. - №70. - 360-368.

16. OG21 - Oil and Gas in the 21st Century. Norway's technology strategy for the 21st centry // C/O The research council of Norway. - 2012. - 64-68.

17. Justification of Hard-to-Recovery Reserves Using Integrated Geological Parameters / A. Shandrygin, D. Dubrovky // Society of Petroleum Engineers. - 2016. [Електронний ресурс]. - Режим доступу: www.onepetro.org/conference-paper/SPE-181908MS (Дата звернення 03.02.2019 р.)

18. Гаричев С. Н. Технология управления в режиме реального времени : учеб. пособие в 2ч. / С. Н. Гаричев, Н. А. Ерёмин. - М. : МФТИ, 2015. - Ч. 1. - 196 с.

19. Recent Development of Digital Oil Field. [Електронний ресурс]. Режим доступу: https://www.scribd.com/document/343694306/Recent-Development-of-Digital-OilField (Дата звернення 03.02.2019 р.)

20. Кочнев А. А. Концепция "интеллектуального" месторождения / А. А. Кочнев // Master's journal. Пермский национальный исследовательский политехнический университет; Под ред. В. Ю. Петрова. - Пермь: Изд-во ПНИПУ, 2015. - № 2. - С. 165-171.

21. Витвицька У. Я. Врахування фактора часу при оцінюванні ефективності інвестицій у нафтогазовидобуванні // Матеріали IV Міжнародної науково-практичної конференції "Надрокористування в Україні. Перспективи інвестування" - К.: ДКЗ, 2017. T. $1 .-302 \mathrm{c}$.

22. Витвицький Я. С. Удосконалення рентного регулювання у нафтовидобуванні / Я. С. Витвицький, Н. О. Гавадзин, І. М. Метошоп, М. С. Пілка // Нафтогазова галузь України. - 2017. - 2 (26). - С. 3-7.

\section{References}

1. British Petroleum: Fossil fuels to remain 'dominant form of energy' through 2035 / by Oil\&Gas Journal editors // Oil\&Gas Journal. - 2016. - [Elektronnyi resurs]. - Rezhym dostupu: http://www.ogj.com/articles/2016/02/bp-fossil-fuels-remain-dominant-form-of-energythrough-2035.html

2. Rozvytok hazovoho sektoru Ukrainy v konteksti Yevrointehratsii // Tsentr Razumkova. - 2014. - [Elektronnyi resurs]. - Rezhym dostupu: http://www.razumkov.org.ua/upload/ 1392037862_file.pdf

3. Do prohnozu osvoiennia vuhlevodnevykh resursiv skhidnoi chastyny DDZ / O. Karpenko, V. Mykhailov, I. Karpenko // Visnyk Kyivskoho natsionalnoho universytetu imeni Tarasa Shevchenka. - 2015. - №1(68). - S.49 54

4. Vytvytska U.Ia. Efektyvnist investytsii u dorozrobku naftovykh rodovyshch Ukrainy: Avtoref. dys. na zdobuttia nauk. stupenia kandydata ekonomichnykh nauk: 08.07.01 / Instytut ekonomiky NAN Ukrainy. - K., 2003. - 20 s.

5. Chorna I.M. Ekonomichna otsinka naftovykh rodovyshch (na prykladi Peredkarpatskoho naftohazonosnoho baseinu): Avtoref. dys. na zdobuttia nauk. stupenia kandydata ekonomichnykh nauk: 08.07.01 / Instytut ekonomiky NAN Ukrainy. - K., 1999. $18 \mathrm{~s}$.

6. Finansovi aspekty innovatsiinoho rozvytku naftohazovoho kompleksu Ukrainy [Tekst]: monohrafiia / L. T. Horal, I. H. Fadieieva ta in. - Ivano-Frankivsk: IFNTUNH, 2016. $325 \mathrm{~s}$.

7. Otsinka efektyvnosti investytsii u rozvidku i rozrobku naftovykh rodovyshch [Tekst]: monohrafiia / Ya.S. Vytvytskyi, U.Ia. Vytvytska, I.M. Metoshop, I.R. Mykhailiv. Ivano-Frankivsk: IFNTUNH, 2006. - 248 s.

8. Pryntsypы ranzhyrovanyia zapasov uhlevodorodov / T.N. Smahyna, S.F. Khafyzov, Y.Y Diakonov, A.N. Shandrbhyn // Neftianoe khoziaistvo. - 2012. - №1. S.20-23 
9. Karpenko I. O. Investytsiina pryvablyvist, konkurentospromozhnist ta opodatkuvannia naftohazovydobuvnoi industrii $\mathrm{v}$ krainakh pivnichnoi Ameryky, skhidnoi Yevropy ta Ukrainy / I. O. Karpenko, O. S. Vednieiev, O. V. Litvinov, I. P. Sereda, O. B. Melnyk // Materialy IV Mizhnarodnoi naukovo praktychnoi konferentsii "Nadrokorystuvannia V Ukraini. Perspektyvy investuvannia" - K.: DKZ, 2017. - T. 1. - 302 s.

10. Kochkodan V. B. Perevahy vykorystannia tekhnolohii intelektualnykh naftohazovykh rodovyshch v Ukraini // Tezy dopovidi na IV Mizhnarodnii naukovo-praktychnii konferentsii "Teoriia i praktyka stratehichnoho upravlinnia rozvytkom haluzevykh i rehionalnykh suspilnykh system" - Ivano-Frankivsk: 2017. - S.142 145

11. Rapid method for oil-field development assessing / D. Khodanovich, R. Malkosh // Oil Industry Journal. - 2017. - [Elektronnyi resurs]. - Rezhym dostupu: www.onepetro.org/journal-paper/OIJ-2017-06-084-087-RU

12. Re-activation of Multilayer Oil Field Development at the Late Stage of Production / Rasim N. Diyashev, N. Nurislamov, V. Voronovsky // Society of Petroleum Engineers. - 2006. - [Elektronnyi resurs]. - Rezhym dostupu: www.onepetro.org/conference-paper/SPE-104361MS

13. Hnyp M.P. Pryntsypы stabylyzatsyy urovnia dobыchy nefty na pozdnei stadyy razrabotky mestorozhdenyi / M.P. Hnyp, V.I. Prokopyv, V.M. Doroshenko // Problemy techniczne i technologiczne pozykiwania weglowodorow a zrownowazony rozwoj gospodarki. Prace Instytutu Nafty I Gazu. - 2006. - № 137. - s. 801-808.

14. Deiaki pytannia vykonannia diiuchykh ta novykh investytsiinykh proektiv (prohram, dohovoriv), yakymy peredbacheno naroshchuvannia vydobutku vuhlevodnevoi syrovyny: postanova KMU vid 7 lystopada 2013 roku №838. Ofitsiinyi sait Kabinetu Ministriv Ukrainy. - Rezhym dostupu: http://zakon5.rada.gov.ua/laws/show/838-2013-p (Data zvernennia 03.05.2018 r.).

15. Zhi, Li Classification of Hard-to-Recover Reserves Based on FCM and Combination weighting approach / Zhi, Li; Juan, Yang; Kejun, Zhu // Wuhan International Conference on e-Business 2013 Proceedings. - 2013. - №70. - p.360-368.

16. OG21 - Oil and Gas in the 21st Century. Norway's technology strategy for the 21st centry // C/O The research council of Norway. - 2012. - p.64-68.

17. Justification of Hard-to-Recovery Reserves Using Integrated Geological Parameters / A. Shandrygin, D. Dubrovky // Society of Petroleum Engineers. - 2016. [Elektronnyi resurs]. - Rezhym dostupu: www.onepetro.org/conference-paper/SPE-181908-MS

18. Harychev S. N. Tekhnolohyia upravlenyia $v$ rezhyme realnoho vremeny : ucheb. posobye v 2ch. / S. N. Harychev, N. A. Erëmyn. - M. : MFTY, 2015. - Ch. 1. - 196 s.

19. Recent Development of Digital Oil Field. [Elektronnyi resurs]. - Rezhym dostupu: https://www.scribd.com/document/343694306/Recent-Development-of-Digital-OilField (Data zvernennia 03.02.2019 r.)

20. Kochnev A. A. Kontseptsyia "yntellektualnoho" mestorozhdenyia / A. A. Kochnev // Masters journal. Permskyi natsyonalnыi yssledovatelskyi polytekhnycheskyi unyversytet; Pod red. V. Yu. Petrova. - Perm: Yzd-vo PNYPU, 2015. - № 2. - S. 165-171.

21. Vytvytska U. Ya. Vrakhuvannia faktora chasu pry otsiniuvanni efektyvnosti investytsii u naftohazovydobuvanni // Materialy IV Mizhnarodnoi naukovo praktychnoi konferentsii "Nadrokorystuvannia v Ukraini. Perspektyvy investuvannia" - K.: DKZ, 2017. - T. 1. $-302 \mathrm{~s}$.

22. Vytvytskyi Ya. S. Udoskonalennia rentnoho rehuliuvannia u naftovydobuvanni / Ya. S. Vytvytskyi, N. O. Havadzyn, I. M. Metoshop, M. S. Pilka // Naftohazova haluz Ukrainy. - 2017. - 2 (26). - S. 3-7. 